\title{
Salmonella plasmids of the pre-antibiotic era
}

\author{
Clive Jones* and John Stanley \\ Plasmid and Molecular Genetics Unit, National Collection of Type Cultures, Central Public Health Laboratory, \\ 61 Colindale Avenue, London NW9 5HT, UK
}

(Received 11 June 1991; revised 6 September 1991; accepted 16 September 1991)

\begin{abstract}
In order to provide a profile of the plasmid gene pool in Salmonella prior to the clinical use of antibiotics, a molecular genetic analysis was made of plasmids in strains collected by E. D. G. Murray between 1917 and 1954. These pre-antibiotic era (PAE) salmonellae contain conjugative plasmids of the same incompatibility groups as contemporary enterobacterial plasmids. Upon analysis of total plasmid content, 42 plasmids, sized between 23 and 72 MDa, were found. We defined and investigated six groups of these PAE Salmonella plasmids in terms of three groups of genes; those involved in plasmid maintenance and incompatibility, DNA repair and virulence. Of the five groups, three were replicon-typed to groups IncI1, IncX and IncFII; one group exhibited no homology to contemporary Inc/Rep probes, and one group represented virulence plasmids containing a common plasmidpartitioning locus. The results indicated that most of the PAE groups were progenitors of contemporary Rplasmids, except for the virulence plasmids, which have generally not evolved as vectors of antibiotic resistance.
\end{abstract}

\section{Introduction}

Pathogenic enterobacteria from human infections of wide geographical distribution between 1917 and 1954 were collected by E. D. G. Murray and were preserved in sealed glass tubes on agar slants. The majority of this Murray collection of pre-antibiotic era (PAE) bacteria consisted of Salmonella (279) and Shigella (177 isolates), with small numbers of Escherichia, Klebsiella and Proteus strains. When opened in 1980 about $70 \%$ were found to be viable. These unique clinical isolates represent bacterial genera in whose contemporary exemplars plasmid-coded multiple antibiotic resistance is widely prevalent and of major clinical significance.

In a study of the PAE plasmids in the Murray Collection, Hughes \& Datta (1983) reported genetic analysis of transferable plasmids among over 400 PAE Enterobacteriaceae. Their analysis was made by testing co-transfer of two small indicator plasmids, which are themselves non-conjugative but mobilizable. Of the PAE isolates $24 \%$ showed ability to mobilize one or both of the indicator plasmids. Among 84 PAE plasmids transferred to $E$. coli $\mathrm{K} 12,47$ were cryptic (mol. mass estimates 25-70 MDa), 36 determined colicinogeny (mol. mass 55-60 MDa) and one encoded tellurite resistance (mol. mass $100 \mathrm{MDa}$ ). None of the transfer-

Abbreviation: PAE, pre-antibiotic era. able PAE plasmids encoded resistance to antibiotics Datta \& Hughes (1983) subsequently labelled these PAE plasmids with the transposons $\operatorname{Tn} 5, \operatorname{Tn} 7$ or $\operatorname{Tn} 9$, and tested them for incompatibility with plasmids of the 21 classical incompatibility groups genetically defined (Datta, 1979) since 1971. Their fundamental finding was that conjugative plasmids of the same Inc groups existed in enterobacteria before and after the medical use of antibiotics. Thus the evolution of R-plasmids occurred by insertion of new resistance genes into a pre-existing enterobacterial plasmid gene pool, rather than by the selected dissemination of R-plasmids which existed prior to the introduction of antibiotics.

The aim of this study was a molecular characterization of the plasmid gene pool present in salmonellae prior to the dissemination of transferable antibiotic resistance and also the provision of a point of reference for comparison with current salmonellae. The type of genetic determinants one might expect to find in these progenitors of contemporary R-plasmids would determine such functions as plasmid maintenance and transfer, gene rearrangement and acquisition systems (e.g. the 'integron'; Grinsted et al., 1990), DNA repair systems, colicins (Hughes \& Datta, 1983) and virulence. We report the molecular characterization of both conjugative and non-conjugative plasmids present in PAE Salmonella strains which were previously shown genetically to contain a conjugative plasmid. This 
complements and completes the original reports (Hughes \& Datta, 1983; Datta \& Hughes, 1983). These archetypal plasmids were further examined for the presence of partition loci, mutagenic DNA repair genes and mousevirulence genes. The original identifications of the PAE Salmonella strains themselves were also re-examined.

\section{Methods}

Bacteria, media, culture conditions. PAE strains of salmonellae are listed in Table $1(a)$, with their isolation dates and the classically derived incompatibility group of the conjugative plasmids isolated from them. They were serotyped by standard methods (Kauffmann, 1972). Where appropriate they were phage-typed by the methods of Ward et al. (1987)

Table 1. Bacterial strains and DNA probes

\begin{tabular}{|c|c|c|c|c|c|}
\hline \multicolumn{6}{|c|}{ (a) $P A E$ salmonellae } \\
\hline $\begin{array}{l}\text { Murray } \\
\text { no. }\end{array}$ & $\begin{array}{l}\text { Original } \\
\text { identification }\end{array}$ & $\begin{array}{l}\text { Correct designation } \\
\text { (where appropriate) }\end{array}$ & $\begin{array}{l}\text { Year of } \\
\text { collection } \dagger\end{array}$ & $\begin{array}{l}\text { Conjugative } \\
\text { Inc group }\end{array}$ & $\begin{array}{l}\text { Plasmid } \\
\text { phenotype }\end{array}$ \\
\hline M131 & $S$. anatum & S. minneapolis & 1938 & Il & ColI \\
\hline M149 & S. typhimurium & & 1935 & I1 & Colla \\
\hline M476 & S. montevideo & & 1939 & Il & Collb \\
\hline $\mathrm{M} 102$ & Salmonella sp. & S. typhimurium & 1941 & Il & ColIb \\
\hline M140 & S. typhimurium & & 1935 & I1 & ColIb \\
\hline M303 & S. typhimurium & & 1941 & I1 & Collb \\
\hline M283 & S. typhimurium & & 1941 & Il & Collb \\
\hline M301 & S. typhimurium & & 1941 & Il & Collb \\
\hline M311 & S. typhimurium & & 1941 & Il & Collb \\
\hline M313 & Salmonella sp. & S. typhimurium & 1941 & II & Collb \\
\hline M496 & Salmonella sp. & S. typhimurium & 1941 & Il & Collb \\
\hline M498 & Salmonella sp. & S. typhimurium & 1941 & Il & Collb \\
\hline M501 & Salmonella sp. & S. typhimurium & 1941 & Il & Collb \\
\hline M503 & Salmonella sp. & S. typhimurium & 1941 & Il & Collb \\
\hline M269 & S. oslo & & 1938 & II & $\mathrm{Col}^{-}$ \\
\hline M141 & S. virchow & & 1938 & Il & $\mathrm{Col}^{-}$ \\
\hline M415 & Salmonella sp. & S. paratyphi B & 1940 & FII & ColB \\
\hline M443 & $S$. bisebjerg & & 1938 & FII & $d r d$ \\
\hline M444 & S. senftenberg & & 1938 & FII & $d r d$ \\
\hline M274 & S. potsdam & & 1938 & $\mathrm{~N}$ & \\
\hline M204 & S. enteritidis & & 1938 & $\mathbf{X}$ & \\
\hline M273 & $S$. moscow & & 1938 & $\mathrm{X}$ & \\
\hline M436 & S. typhimurium & S. paratyphi C & 1931 & $\mathrm{X}$ & \\
\hline M46 & S. typhi & & 1939 & $\mathbf{X}$ & \\
\hline M507 & S. typhi & & 1937 & $\mathbf{X}$ & \\
\hline M21 & S. typhimurium & & 1917 & $\mathrm{X}$ & \\
\hline M25 & Salmonella sp. & S. choleraesuis & 1926 & $x$ & \\
\hline M581 & S. typhi & & 1935 & $\mathrm{x}$ & \\
\hline M155 & S. typhimurium & & 1938 & $\mathbf{X}$ & \\
\hline M506 & S. eastbourne & & 1938 & Unclassed & \\
\hline M527 & Salmonella sp. & Enterobacter sp. & 1940 & Unclassed & \\
\hline M530 & Salmonella sp. & Enterobacter sp. & 1940 & Unclassed & \\
\hline
\end{tabular}

(b) DNA probes

\begin{tabular}{|c|c|c|c|c|}
\hline Probe & Fragment/size (kb) & $\begin{array}{l}\text { Plasmid of } \\
\text { origin }\end{array}$ & Cloned in: & Reference \\
\hline FIA & EcoRI $/ 0.9$ & $\mathrm{~F}$ & pULB2154 & Couturier et al. (1988); NCTC 50547 \\
\hline FIB & Pst $\mathrm{I} / 1 \cdot 2$ & P307 & pULB2404 & Couturier et al. (1988); NCTC 50549 \\
\hline FIC & EcoRI-HindIII/0.97 & P307 & pULB2440 & Couturier et al. (1988); NCTC 50550 \\
\hline FIIA & Pst $\mathrm{I} / 0.5$ & R1drd-19 & pULB2401 & Couturier et al. (1988); NCTC 50551 \\
\hline Il & EcoRI-Pst $\mathrm{I} / \mathbf{1} \cdot 1$ & R64drd-11 & pULB2428 & Couturier et al. (1988); NCTC 50553 \\
\hline $\mathbf{N}$ & EcoRI/1.0 & R46 & pULB2406 & Couturier et al. (1988); NCTC 50555 \\
\hline $\mathbf{X}_{\mathrm{R} 6 \mathrm{~K}}$ & HindIII $/ 0.9$ & R6K & pULB2405 & Couturier et al. (1988); NCTC 50545 \\
\hline $\mathbf{X}_{\mathrm{R} 485}$ & EcoRI-TaqI $/ 0.59$ & R485 & pDS49 & Stalker \& Helinski (1985) \\
\hline par & $E c o R V / 1.9$ & pStSR 100 & pYA22027 & Tinge \& Curtiss $(1990 a)$ \\
\hline VirA & $E c o R I / 4 \cdot 1$ & pIP1350 & pIP1367 & Norel et al. $(1989 a)$ \\
\hline VirB & Clal $/ 2 \cdot 9$ & pIP1350 & pIP1366 & Norel et al. $(1989 a)$ \\
\hline $\operatorname{imp} C A B$ & $\begin{array}{l}E c o R V / 1.75 \text { and } \\
E c o \text { I }-E c o R V / 1.0\end{array}$ & TP110 & pKG10 & Glazebrook et al. (1986) \\
\hline$m u c A B$ & HincII $/ 1 \cdot 1$ and 0.9 & pKM101 & pIC80 & Herrera et al. (1988) \\
\hline
\end{tabular}

- Ordered according to the incompatibility group of the conjugative plasmid identified in the host strain by Hughes \& Datta (1983).

† Year of addition into Murray Collection - usually the date of isolation but a few had been isolated earlier. 
for S. enteritidis, Callow (1959) for $S$. typhimurium, Cragie \& Felix (1947) for S. typhi and Chambers et al. (1987) for S. virchow. Salmonella and Escherichia coli strains were stored on nutrient agar slopes at room temperature and grown on nutrient agar/broth at $37^{\circ} \mathrm{C}$ for $18 \mathrm{~h}$. Antibiotics (Sigma) were added to media for growth of DNA probe strains, at the following concentrations $\left(\mu \mathrm{g} \mathrm{ml}^{-1}\right)$ : ampicillin (100), chloramphenicol (25), tetracycline (10).

Plasmid analysis and DNA hybridization. PAE Salmonella strains were screened for plasmid content by the method of Kado \& Liu (1981), and plasmids were visualized by electrophoresis on double-origin, horizontal $0.7 \%$ agarose gels. Gels were poured with combs spaced $6 \mathrm{~cm}$ apart permitting 36 samples to be run simultaneously (see Fig. 1a). Agarose gels were vacuum-blotted (Pharmacia-LKB Vacu-Gene apparatus) onto Hybond nylon membrane (Amersham). Plasmid DNA for preparation of probe fragments was extracted from $500 \mathrm{ml}$ nutrient broth cultures by cleared lysis and caesium chloride/ethidium bromide density gradient purification (Maniatis et al., 1982). DNA probes were digested with the enzymes reported in Table $1(b)$ (Gibco-BRL, used according to manufacturer's instructions). Restriction fragments were separated on $1 \%$ low melting point agarose (Gibco-BRL). They were labelled with digoxygenin-11-dUTP (Boehringer) by random-primed synthesis in agarose. Membrane filters were hybridized at $68^{\circ} \mathrm{C}$ in $5 \times \mathrm{SSC}$, washed (final wash in $0.1 \times \mathrm{SSC}$ at $55^{\circ} \mathrm{C}$ ), and colourdeveloped according to Boehringer instructions. DNA probe fragments used in this study are listed in Table $1(b)$.

\section{Results}

\section{Serotyping and phage-typing}

Thirty-two strains of PAE Salmonella were examined. Following new biotyping and serotyping analysis, two of these strains (M527 and M530) were transferred to the genus Enterobacter and two were assigned to different serovars: $S$. typhimurium M436 as $S$. paratyphi $\mathrm{C}$ and $S$. anatum M131 as $S$. minneapolis. Another eight strains formerly identified only as Salmonella sp. were assigned to the serovars $S$. typhimurium, $S$. paratyphi B and $S$. choleraesuis (see Table 1). The phage types, where known, are given in Table 2.

\section{Plasmid characterization : general considerations}

Plasmid detection and yield by the procedure of Kado \& Liu (1981) was not noticeably different for the PAE strains from results with contemporary salmonellae (our unpublished observations). Forty-two plasmids in all were detected; among these only two plasmids showed consistently low yield. A $25 \mathrm{MDa}$ IncX plasmid of S. typhi gave an undetectable low yield in many agarose gel experiments (faint lower plasmid band in track 30 of Fig. 1a) but nonetheless hybridized with DNA probes. A $24 \mathrm{MDa}$ IncFII plasmid of $S$. seftenberg was visible in agarose gels (track 21, Fig. 1a). Other Salmonella plasmids, detected reproducibly, varied in size between $23 \mathrm{MDa}$ and $72 \mathrm{MDa}$ ('cryptic' plasmids of $S$. potsdam
M274). With respect to size classes, the largest was the $65 \mathrm{MDa}$ class, all but four of which were present in $S$. typhimurium. The next largest was the $25 \mathrm{MDa}$ class, spread between serovars $S$. choleraesuis, $S$. enteritidis, $S$. moscow, $S$. typhimurium and $S$. typhi. All other size classes (Table 2) had only one or two representatives. Twenty PAE Salmonella strains contained only a single plasmid. It is noteworthy that of the twenty such strains, only one was a (mouse) virulence plasmid (S. paratyphi C M436), whilst that of the others belonged to other plasmid types (twelve IncI1, four IncX, two IncFII and one unclassed exemplar).

The other ten strains contained two plasmids. In four serovars ( $S$. enteritidis, $S$. moscow, $S$. typhi, $S$. typhimurium) IncX and virulence plasmids co-existed. In $S$. typhimurium IncIl plasmid(s) co-existed with either virulence plasmids (two strains) or IncFII plasmids (two strains).

In order to correlate the hybridization data and the classical Inc-typing results of Datta \& Hughes (1983), the primary E. coli $\mathrm{K} 12$ transconjugants containing conjugative Salmonella plasmids were also analysed (data not shown). The sizes of the transferred plasmids were compared to plasmids in the PAE salmonellae (Table $1 a$ ) by running samples side-by-side in agarose gel tracks. All strains, M131 to M506, were shown to contain a plasmid of equivalent molecular mass. In cases where more than one plasmid co-existed, the original conjugative plasmid was thereby identified. These are indicated by asterisks in Table 2.

The overall approach was to order the strains as in Table 1(a), viz. according to the previously reported presence of a conjugative plasmid of known Inc group. This order was preserved in all gel analyses (see Fig. 1a) and their related hybridization experiments (Figs $1 b, 2 a$, $b$ ). The thirteen DNA probes defined in Table $1(b)$ were hybridized with individual Southern blots and washed under stringent conditions as described in Methods.

\section{IncII PAE plasmids carrying mutagenic DNA repair genes}

Five serovars contained large (62-65 MDa) plasmids which hybridized with two of the eight replicon probes, I1 and FIC. This pattern of hybridization identified them as belonging to the Inc group Il (Couturier et al., 1988). It should be noted that the FIC probe also hybridizes with plasmids of Inc group FII. However, these are distinguished from Inc group I1 plasmids by their failure to hybridize with the I1 probe and their hybridization with the FIIA probe. (Compare $S$. paratyphi B M415 and S. minneapolis M131 in Table 2.)

In two $S$. typhimurium strains, M149 and M140, the I1hybridizing plasmid co-migrated with a similarly sized 


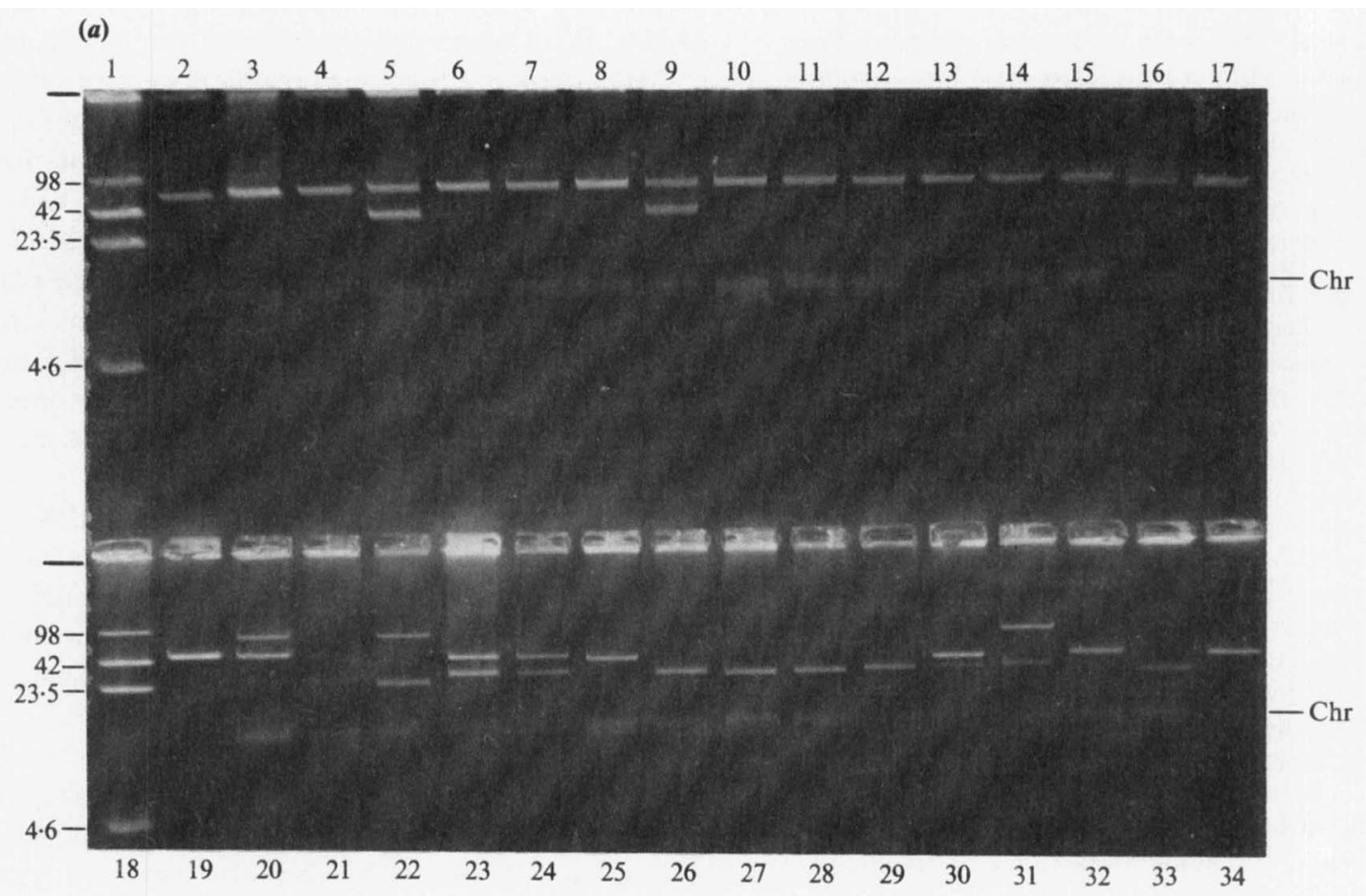

(b)

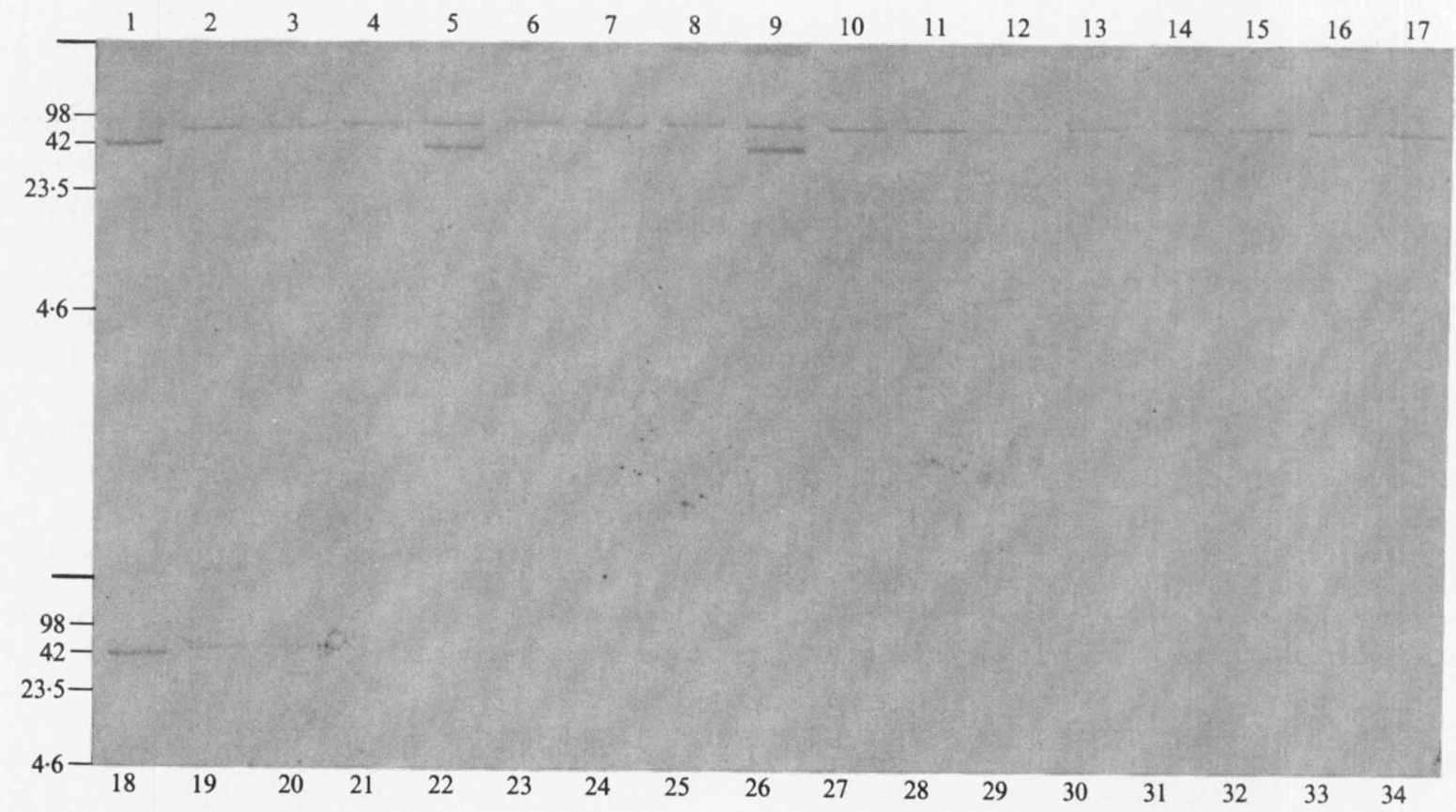

Fig. 1. The plasmid content of the strains is shown, and represents the standard gel format blotted for all experiments (cf. Figs $1 b$ and $2 a$, $b$ for example). Plasmid molecular mass standards (strain 39R861; NCTC 50192) are shown in tracks 1 and 18, labelled in MDa on the left. Chromosomal fragments (Chr) are indicated. The tracks contained: $1, \mathrm{M} 131 ; 2, \mathrm{M} 149 ; 3, \mathrm{M} 476 ; 4, \mathrm{M} 102 ; 5, \mathrm{M} 140 ; 6, \mathrm{M} 303 ; 7$, M283;8, M301;9, M311;10, M313;11, M496; 12, M498; 13, M501; 14, M503; 15, M269; 16, M141; 17, M415; 18, 39R861; 19, M443; 20, M415; 21, M444;22, M274;23, M204;24, M273;25, M436; 26, M46; 27, M507; 28, M21; 29, M25; 30, M581;31, M155;32, M506; 33, M527; 34, M530. (b) Southern blot of gel as shown in $(a)$ hybridized with the FIC replicon probe.

virulence plasmid. (Fig. $1 a$, tracks 3 and 8 , appear as 'single' strong bands.) The existence of two plasmids in these cases were resolved by examining Pst I digests of total plasmids DNA from the strains (data not shown). In two S. typhimurium strains of phage type 100, the IncI1 plasmid co-existed with a smaller plasmid (Fig. 1a, 
Table 2. Molecular characterization of the plasmids

+ or - indicates homology or no homology detected under the conditions described in Methods. DNA probes FIA, FIB, $\mathrm{X}_{\mathbf{R} 6 \mathrm{~K}}$ and muc were also tested against these plasmids but no homologies were found.

\begin{tabular}{|c|c|c|c|c|c|c|c|c|c|c|c|c|}
\hline \multirow{2}{*}{$\begin{array}{l}\text { Murray } \\
\text { no. }\end{array}$} & \multirow[b]{2}{*}{ Designation } & \multirow{2}{*}{$\begin{array}{l}\text { Phage } \\
\text { type }\end{array}$} & \multirow{2}{*}{$\begin{array}{l}\text { Mol. } \\
\text { mass } \\
\text { (MDa) }\end{array}$} & \multicolumn{9}{|c|}{ DNA probe homologies } \\
\hline & & & & FIC & FIIA & I1 & par & $\mathbf{N}$ & $X_{R 485}$ & VirA & VirB & $i m p$ \\
\hline M131 & $S$. minneapolis & & $65^{*}$ & + & - & + & - & - & - & - & - & + \\
\hline \multirow[t]{2}{*}{ M149 } & S. typhimurium & 4 & $65^{*} \dagger$ & + & - & + & - & - & - & - & - & + \\
\hline & & & $65 \dagger$ & - & - & - & + & - & - & + & + & - \\
\hline M476 & $S$. montevideo & & $65^{*}$ & + & - & + & - & - & - & - & - & + \\
\hline \multirow[t]{2}{*}{ M 102} & S. typhimurium & 100 & $65^{*}$ & + & - & + & - & - & - & - & - & + \\
\hline & & & 34 & + & + & - & - & - & - & - & - & - \\
\hline \multirow[t]{2}{*}{ M140 } & S. typhimurium & RDNC $\ddagger$ & $65^{*}+$ & + & - & + & - & - & - & - & - & + \\
\hline & & & $65 t$ & - & - & - & + & - & - & + & + & - \\
\hline M303 & S. typhimurium & 12 & $65^{*}$ & + & - & + & - & - & - & - & - & + \\
\hline M283 & S. typhimurium & 12 & $65^{\circ}$ & + & - & + & - & - & - & - & - & + \\
\hline \multirow[t]{2}{*}{ M301 } & S. typhimurium & 100 & $65^{\circ}$ & + & - & + & - & - & - & - & - & + \\
\hline & & & 34 & + & + & - & - & - & - & - & - & - \\
\hline M311 & S. typhimurium & 12 & $65^{*}$ & + & - & + & - & - & - & - & - & + \\
\hline M313 & S. typhimurium & 132 & $65^{*}$ & + & - & + & - & - & - & - & - & + \\
\hline M496 & S. typhimurium & 12 & $65^{*}$ & + & - & + & - & - & - & - & - & + \\
\hline M498 & S. typhimurium & 100 & $65^{*}$ & + & - & + & - & - & - & - & - & + \\
\hline M501 & S. typhimurium & 20 & $65^{*}$ & + & - & + & - & - & - & - & - & + \\
\hline M503 & $S$. typhimurium & 100 & $65^{*}$ & + & - & + & - & - & - & - & - & + \\
\hline M269 & S. oslo & & $62^{*}$ & + & - & + & - & - & - & - & - & + \\
\hline M141 & S. virchow & 34 & $62^{*}$ & + & - & + & - & - & - & - & - & + \\
\hline M415 & S. paratyphi B & & $48^{*}$ & + & + & - & - & - & - & - & - & - \\
\hline \multirow[t]{2}{*}{ M443 } & $S$. bisebjerg & & 70 & - & - & - & + & - & - & - & + & - \\
\hline & & & $48^{*}$ & + & + & - & - & - & - & - & - & - \\
\hline M444 & $S$. senftenberg & & $24^{*}$ & - & - & - & - & - & - & - & - & - \\
\hline \multirow{2}{*}{ M274 } & S. potsdam & & 72 & - & - & - & - & - & - & - & - & - \\
\hline & & & $23^{*}$ & - & - & - & - & - & - & - & - & - \\
\hline \multirow[t]{2}{*}{ M204 } & S. enteritidis & $6 a$ & 38 & - & - & - & + & - & - & + & + & - \\
\hline & & & $26^{*}$ & - & - & - & - & - & + & - & - & - \\
\hline \multirow[t]{2}{*}{ M273 } & $S$. moscow & & 38 & - & - & - & + & - & - & + & + & - \\
\hline & & & $26^{*}$ & - & - & - & - & - & + & - & - & - \\
\hline M436 & S. paratyphi C & & $36^{*}$ & - & - & -- & + & - & - & + & + & - \\
\hline M46 & S. typhi & 46 & $25^{\circ}$ & - & - & - & - & - & + & - & - & - \\
\hline M507 & S. typhi & & $25^{*}$ & - & - & - & - & - & + & - & - & - \\
\hline M21 & S. typhimurium & RDNC $\ddagger$ & $25^{*}$ & - & - & - & - & - & + & - & - & - \\
\hline \multirow[t]{2}{*}{ M25 } & S. choleraesuis & & 30 & - & - & - & + & - & - & + & + & - \\
\hline & & & $25^{*}$ & - & - & - & - & - & + & - & - & - \\
\hline M581 & S. typhi & & $25^{*}$ & - & - & - & - & - & + & - & - & - \\
\hline \multirow[t]{2}{*}{ M155 } & S. typhimurium & & 60 & - & - & - & + & - & - & + & + & - \\
\hline & & & $25^{*}$ & - & - & - & - & - & + & - & - & - \\
\hline M506 & S. eastbourne & & $32^{*}$ & - & - & - & - & - & - & - & - & - \\
\hline
\end{tabular}

- Conjugative plasmid as originally identified by Datta \& Hughes (1983).

+ Strain carries two co-migrating plasmids. On separation the imp/I1/FIC homologies were located on a Il plasmid, while the VirA,B/par homologies on the other plasmid (data not shown).

$\ddagger$ Reacted with $S$. typhimurium typing phages but did not conform to any designated pattern.

tracks 5 and 9) which was identified as IncFII. By the above criteria, sixteen strains contained IncIl plasmids. By comparison with the primary E. coli transconjugants of Datta \& Hughes (1983) it was established that all these plasmids were conjugative. The entire plasmid set was next hybridized with cloned genes encoding mutagenic DNA repair functions. These were the impCAB locus of the IncIl plasmid TP110 (Glazebrook et col., 1986), and the mucAB locus of the IncN plasmid pKM101 (Herrera et al., 1988). In our experiments all sixteen PAE IncI1 plasmids hybridized positively with the impCAB probe, whilst none of the other 26 plasmids did so.

\section{PAE IncX plasmids}

Two types of contemporary IncX plasmids have been distinguished on the basis of their non-homologous replicons. The corresponding replication loci have been cloned from the plasmid R6K (Couturier et al., 1988), which was isolated from E. coli, and from R485 (Stalker \& Helinski, 1985), which was isolated from Proteus morganii. Both these probes were employed to screen for IncX PAE plasmids. The R6K probe detected no homologous replicons. The R485 probe detected eight IncX PAE replicons, all around the same size (25 MDa; 

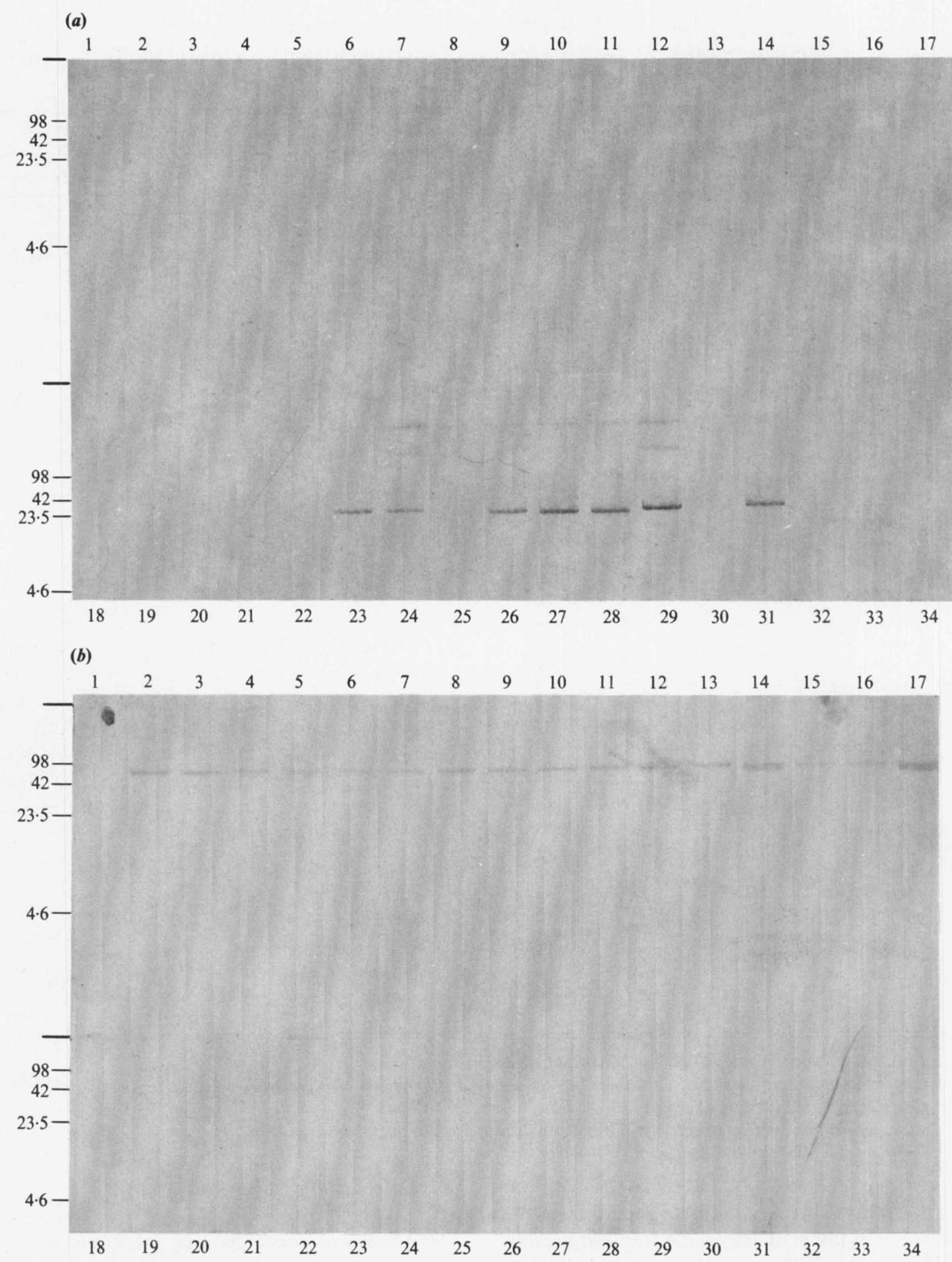

Fig. 2. (a) Southern blot (for format cf. Fig. 1) hybridized with the IncX replicon probe. (b) Southern blot (cf. Fig. 1) hybridized with the IncIl replicon probe.

Table 2) and distributed in five serovars, $S$. choleraesuis, $S$. enteritidis, $S$. moscow, $S$. typhi and $S$. typhimurium. Numerically, IncX plasmids represented the second largest plasmid class among these PAE salmonellae.
PAE virulence plasmids

The plasmid blots were screened for homology with probes containing the VirA, VirB (Norel et al., 1989a) 
Table 3. Occurrence of PAE plasmid classes in the Salmonella serovars

\begin{tabular}{|c|c|c|}
\hline $\begin{array}{l}\text { Plasmid } \\
\text { class }\end{array}$ & $\begin{array}{l}\text { No. of } \\
\text { examples }\end{array}$ & $\begin{array}{l}\text { Serovar and (no. of } \\
\text { plasmids found) }\end{array}$ \\
\hline Il & 16 & $\begin{array}{l}\text { S. minneapolis (1) } \\
\text { S. montevideo (1) } \\
\text { S. oslo (1) } \\
\text { S. typhimurium (12) } \\
\text { S. virchow (1) }\end{array}$ \\
\hline $\mathbf{X}$ & 8 & $\begin{array}{l}\text { S. choleraesuis (1) } \\
\text { S. enteritidis (1) } \\
\text { S. moscow (1) } \\
\text { S. typhimurium (2) } \\
\text { S. typhi (3) }\end{array}$ \\
\hline $\operatorname{Vir} A^{+}$ & 7 & $\begin{array}{l}S . \text { choleraesuis (1) } \\
\text { S. enteritidis (1) } \\
S . \text { moscow (1) } \\
\text { S. paratyphi C (1) } \\
\text { S. typhimurium (3) }\end{array}$ \\
\hline FIIA & 4 & $\begin{array}{l}\text { S. bisebjerg (1) } \\
\text { S. paratyphi B (1) } \\
\text { S. typhimurium (2) }\end{array}$ \\
\hline
\end{tabular}

and par (Tinge \& Curtiss, $1990 a$ ) loci previously cloned from the $S$. typhimurium virulence plasmid. An identical pattern of positive hybridization was found with each of these probes, with a single plasmid of seven strains belonging to the five serovars $S$. typhimurium, $S$. enteritidis, $S$. moscow, $S$. paratyphi $\mathrm{C}$ and $S$. choleraesuis (see also Table 3). Under the stringent conditions used in this study no homologies were found for the FIB or FIIA probes. The sizes of these serotype-specific virulence plasmids were, respectively, 60, 38, 38, 36 and $30 \mathrm{MDa}$. Interestingly, S. enteritidis M204 and S. moscow M273, which are closely related serologically, each contained co-existing IncX and virulence plasmids. The two plasmids were of the same molecular masses in each serovar (compare Fig. $1 a$, tracks 23 and 24, where the upper band is the plasmid hybridizing with the par probes).

\section{Other PAE plasmids: IncFII and unclassed}

The next largest class of PAE plasmids was made up of those hybridizing with both the FIIA and FIC probes. Fig. 1 $(b)$ shows the FIC probe data and four strains (tracks 5, 9,19 and 20) subsequently also hybridized with the FIIA probe. In tracks 5 and 9, the plasmids concerned are the smaller of the two FIC-positives. This result identified two $34 \mathrm{MDa}$ plasmids of $S$. typhimurium, and two $48 \mathrm{MDa}$ plasmids in S. paratyphi and S. bisebjerg as belonging to IncFII (criteria of Couturier et al., 1988).

A single exemplar previously published as plasmid incompatibility group $\mathrm{N}$ was found in S. potsdam M274. It did not hybridize with the probe for IncN (Table $1 b$ ) or with $m u c A B$, which are plasmid-borne genes encoding DNA mutagenic repair in some contemporary IncN plasmids like R46.

The $70 \mathrm{MDa}$ plasmid of $S$. bisebjerg cannot be considered a virulence plasmid as it hybridized only with par and vir $B$ and not with the vir $A$ probe. Both these regions are concerned with plasmid stability and not directly with virulence functions.

Two other plasmids were observed which failed to hybridize with any tested probe. One of these had transferred an indicator plasmid in the genetic system of Hughes \& Datta (1983); this was the $32 \mathrm{MDa}$ plasmid of $S$. eastbourne M506. The other, $72 \mathrm{MDa}$, was detected uniquely in these experiments, in $S$. potsdam M274, where it co-existed with the 'IncN' plasmid discussed above.

\section{Discussion}

Couturier et al. (1988) have developed a molecular classification of plasmids on the basis of their 'basic replicon' content, i.e. the genes required for autonomous plasmid replication and its control. The 'basic replicon' of a plasmid may be cloned as a locus expressing incompatibility functions associated with its replication. These clones were then used as DNA probes, enabling identification of plasmids belonging to different incompatibility groups by molecular replicon typing. Many multi-replicon plasmids which gave ambivalent results by classical phenotypic Inc typing have been thus unequivocally characterized. This Inc/Rep method characterized five Inc groups among the PAE Salmonella plasmids, whilst a sixth group, representing virulence plasmids, did not react with the Inc/Rep probes listed in Table 1. This contrasts with the findings of Pohl et al. (1987) who found that the virulence plasmid of $S$. typhimurium hybridized with both the FIA and FII probes. Therefore, we deduce that Salmonella virulence plasmids have replicons which are related but not identical to IncFI and IncFII plasmids. Tinge \& Curtiss $(1990 b)$ reached a similar conclusion on the basis of weak homology of the replication regions of the $S$. typhimurium virulence plasmid R100 (IncFII) of F (IncFI). Sixteen Incll plasmids were detected (Table 2), as determined by reaction with FIC and I1 probes. We discuss these below in terms of their carriage of DNA repair determinants.

Eight IncX PAE plasmids of about $25 \mathrm{MDa}$ were observed to hybridize with the R485, but not the R6K replicon probe. $R 6 \mathrm{~K}$ is, in fact, the only example of this IncX replicon type reported. $R 485$ is a contemporary plasmid carrying only sulphonamide resistance. Other contemporary R485-type replicons identified carried multiple resistances encoded by identifiable transposons 
$\operatorname{Tn} 3, \operatorname{Tn} 7$ and $\operatorname{Tn} 21$ (D. Osborne and C. Jones, unpublished). In this case the data clearly show the evolution of R-plasmids from progenitor PAE plasmids by acquisition of transposable resistance genes. Four IncFII PAE plasmids were identified. The IncFII group of contemporary enterobacteria contains numerous examples of multiple antibiotic resistance plasmids such as R100 (Watanabe et al., 1964). The transfer system of R100 has been particularly well-studied at a molecular genetic level (reviewed by Willetts \& Skurray, 1980) and this plasmid was also the source of the multi-resistance transposon $\mathrm{Tn} 21$ which carries a highly recombinogenic gene-acquisition system termed an 'integron' (Grinsted et al., 1990).

Two classes of plasmid-borne mutagenic DNA repair genes have been characterized. These are mucAB, restricted to IncN plasmids, and $i m p C A B$, found in Incll and IncB plasmids (reviewed by Strike \& Lodwick, 1987). Functional homologues of the $\operatorname{imp} C A B$ locus of contemporary plasmids were shown to exist in two Murray PAE plasmids of Inc groups II and B by Sedgewick et al. (1989). This $100 \%$ conserved linkage of imp genes to IncIl replicons may be contrasted with the variability reported (Hughes \& Datta, 1983) for the colicin phenotype of these plasmids: the PAE IncIl plasmids either did not encode colicins or encoded one of three types, ColIb, Colla or ColI. Of nine contemporary IncIl plasmids tested seven carried the $\operatorname{imp} C A B$ locus (reviewed by Strike \& Lodwick, 1987), along with single (e.g. TP110) or multiple antibiotic resistances (e.g. R62).

Five serovars contained plasmids hybridizing with the VirA locus which was cloned from a large plasmid of $S$. typhimurium LT2 and which suppresses the fertility of plasmid $F$ and also confers a virulence phenotype in mouse infection studies. This virulence plasmid has been variously termed pSLT (Jones et al., 1982), pLT2 (Brown et al., 1986), pIP1350 (Norel et al., 1989a), pEX102 (Rhen et al., 1989) and pStSR100 (Tinge \& Curtiss, $1990 a$ ). Two linked loci of this plasmid have been characterized in some detail - they are termed VirA and VirB. Physical -genetic maps of both regions have been presented (e.g. Norel et al., 1989a). Four genes in the VirA region of $S$. typhimurium have been characterized to the nucleotide sequence level and are termed $m k f$ (mouse $k$ illing factor) $A, m k f B$, ORF2 (Norel et al., 1989b, c) and vag $A$ (Pullinger et al., 1989). The VirA region is conserved in plasmids of 11 contemporary serovars of salmonellae (Williamson et al., 1988). The virulence genes of one of these serovars, $S$. choleraesuis, have been shown to be conserved at the sequence level (Matsui et $a l ., 1990 a, b)$. Virulence plasmids have characteristic incompatibility behaviour with respect to homologous plasmids of other Salmonella serovars (Ou et al., 1990).
Brown et al. (1986) and Woodward et al. (1989) have provided evidence that possession of these large plasmids is a serotype-specific property. A plasmid-partitioning (par) locus which is also responsible for incompatibility has been cloned from the virulence plasmid of S. typhimurium (Tinge \& Curtiss, 1990a) and is invariably linked to VirA-carrying plasmids (Tinge \& Curtiss, $1990 b$ ). The fact that PAE virulence plasmids of $S$. typhimurium, $S$. enteritidis and $S$. choleraesuis hybridized positively with the partition locus (par) probe is consistent with the report that these virulence plasmids are incompatible with each other in contemporary serovars (Ou et al., 1990). The molecular masses of PAE virulence plasmids observed were not different from those reported for contemporary representatives of the five serovars where they were found (Ou et al., 1990, Woodward et al., 1989). Of the six PAE serovars which contained plasmids hybridizing with par, three ( $S$. typhimurium, $S$. choleraesuis and $S$. enteritidis) contemporary serovars have been reported to harbour plasmids which do so (Tinge \& Curtiss, 1990b). Our results indicate that Salmonella virulence plasmids have not undergone detectable molecular evolution under the influence of antibiotic selection pressure. This is not unexpected, since they are serotype-specific, poorly transferable and are not vectors of antibiotic resistance.

The data presented in this report provide a molecular picture of Salmonella plasmids prior to the imposition of selective pressure due to the medical and agricultural use of antibiotics. As such the data provide a 'baseline' for the study of molecular evolution in the plasmid groups analysed and it could be, for instance, usefully compared with results from present-day salmonellae at the levels of individual plasmid loci, of plasmid classes, and of population genetics.

We are greatly indebted to M. L. M. Hall and L. R. Ward of the Division of Enteric Pathogens for serotyping the PAE Salmonella isolates. We thank E. J. Threlfall for critically reading this manuscript. We thank Steven Sedgewick, Peter Strike and Roy Curtiss III for kind gifts of DNA probes.

\section{References}

Brown, A. M. C. \& WilletTs, N. S. (1981). A physical and genetic map of the IncN plasmid R46. Plasmid 5, 188-201.

Brown, D. J., Munro, D. S. \& Platt, D. J. (1986). Recognition of the cryptic plasmid pSLT, by restriction fingerprinting and a study of its incidence in Scottish salmonella isolates. Journal of Hygiene 97, 193197.

Callow, B. R. (1959). A new phage-typing scheme for Salmonella typhimurium. Journal of Hygiene 57, 346-359.

Chambers, R. M., McAdam, P., De SA, J. D. H., Ward, L. R. \& Rowe, B. (1987). A phage-typing scheme for Salmonella virchow. FEMS Microbiology Letters 40, 155-157.

Couturier, M., Bex, F., Berquist, P. L. \& MaAs, W. K. (1988). Identification and classification of bacterial plasmids. Microbiological Reviews 52, 375-395. 
Craigie, J. \& Felix, A. (1947). Typing of typhoid bacilli with $\mathrm{Vi}$ bacteriophage. Lancet i, 823-827.

DatTa, N. (1979). Plasmid classification: incompatibility grouping. In Plasmids of Medical, Environmental and Commercial Importance, pp. 3-12. Edited by K. N. Timmis \& A. Puhler. Amsterdam: Elsevier/North Holland Press.

Datta, N. \& Hughes, V. M. (1983). Plasmids of the same Inc groups in enterobacteria before and after the medical use of antibiotics. Nature, London 306, 616-617.

FEE, B. E. \& DeMPSEY, W. B. (1986). Cloning, mapping, and sequencing of plasmid R 100 traM and finP genes. Journal of Bacteriology 167, 336-345.

Glazebrook, J. A., Grewal, K. K. \& Strike, P. (1986). Molecular analysis of the UV protection and mutation genes carried by the I incompatibility group plasmid TP110. Journal of Bacteriology 168 , 251-256.

Grinsted, J., DE lA CRUZ, F. \& SChmitt, R. (1990). The Tn21 subgroup of bacterial transposable elements. Plasmid 24, 163-189.

Herrera, G., Urios, A., Aleixandre, V. \& Blanco, M. (1988). UV light-induced mutability in Salmonella strains containing the umuDC or the mucAB operon: evidence for a $u m u C$ function. Mutation Research 198, 9-13.

Hughes, V. M. \& DAtTA, N. (1983). Conjugative plasmids in bacteria of the 'pre-antibiotic' era. Nature, London 302, 725-726.

Jones, G. W., Rabert, D. K., Svinarich, D. M. \& Whitfield, H. J. (1982). Association of adhesive, invasive and virulent phenotypes of Salmonella typhimurium with autonomous 60 -megadalton plasmids. Infection and Immunity 38, 476-486.

KADO, C. I. \& LiU, S.-T. (1981). Rapid procedure for detection of large and small plasmids. Journal of Bacteriology 145, 1365-1375

Kauffmann, F. (1972). Serological Diagnosis of Salmonella Species. Copenhagen: Munksgaard.

Maniatis, T., Fritsch, E. F. \& SAmbroOK, J. (1982). Molecular Cloning. A Laboratory Manual. Cold Spring Harbor, NY: Cold Spring Harbor Laboratory.

Matsui, H., Kawahara, K., Terakado, N. \& Danbara, H. (1990a). Nucleotide sequence of a gene encoding a $29 \mathrm{kDa}$ polypeptide in $\mathrm{mba}$ region of the virulence plasmid, pKDS50, of Salmonella choleraesuis. Nucleic Acids Research 18, 1055.

Matsui, H., Kawahara, K., Terakado, N. \& Danbara, H. (1990a). Nucleotide sequences of genes encoding $32 \mathrm{kDa}$ and $70 \mathrm{kDa}$ polypeptides in mba region of the virulence plasmid, pKDS50, of Salmonella choleraesuis. Nucleic Acids Research 18, 1055.

Norel, F., Coynault, C., Miras, I., Hermant, D. \& Popoff, M. Y. $(1989 a$ ). Cloning and expression of plasmid DNA sequences involved in Salmonella serotype typhimurium virulence. Molecular Microbiology 3, 733-743.

Norel, F., Coynault, C., Miras, I., hermant, D. \& Popoff, M. Y. $(1989 b)$. Nucleotide sequence of the plasmid-borne virulence gene mkfA encoding a $28 \mathrm{kd}$ polypeptide from Salmonella typhimurium. Research in Microbiology 140, 263-265.
Norel, F., Coynault, C., Miras, I., Hermant, D. \& Popoff, M. Y. $(1989 c)$. Nucleotide sequence of the plasmid-borne virulence gene $m k f B$ encoding a $28 \mathrm{kd}$ polypeptide from Salmonella typhimurium. Research in Microbiology 140, 455-457.

Ou, J. T., Baron, L. S., DaI, X. \& LifE, C. A. (1990). The virulence plasmids of Salmonella serovars typhimurium, choleraesuis, dublin and enteritidis, and the cryptic plasmids of Salmonella serovars copenhagen and sendai belong to the same incompatibility group, but not those of Salmonella serovars durban, gallinarum, give, infantis and pullorum. Microbial Pathogenesis 8, 101-107.

Pohl, P., Lintermans, F., Bex, F., Desmyter, A., Dreze, P., Fonteyne, P. A. \& Couturier, M. (1987). Propriétés phénotypiques et génotypiques de quartre plasmides de virulence de Salmonella typhimurium. Annals de l'Institut Pasteur/Microbiologie 138, 523-528.

Pullinger, G. D., Baird, G. D., Williamson, C. M. \& Lax, A. J. (1989). Nucleotide sequence of a plasmid gene involved in the virulence of salmonellas. Nucleic Acids Research 17, 7983.

Rhen, M., Virtanen, M. \& Makela, P. H. (1989). Localization by insertional mutagenesis of a virulence-associated region in the Salmonella typhimurium 96 kilobase pair virulence plasmid. Microbial Pathogenesis 6, 153-158.

SeDgewick, S. G., Thomas, S. M., Hughes, V. M., Lodwick, D. \& STRIKE, P. (1989). Mutagenic DNA repair genes on plasmids from the 'pre-antibiotic era'. Molecular and General Genetics 218, 323-329.

Stalker, D. M. \& Helinski, D. R. (1985). DNA Segments of the IncX plasmid R485 determining replication and incompatibility with R6K. Plasmid 14, 245-254.

STRIKE, P. \& LoDWICK, D. (1987). Plasmid genes affecting DNA repair and mutation. Journal of Cell Science (Suppl.) 6, 303-321.

TINGE, S. A. \& CURTISS, R., III, (1990a). Isolation of the replication and partitioning regions of the Salmonella typhimurium virulence plasmid and stabilization of heterologous replicons. Journal of Bacteriology 172, 5266-5277.

TINGE, S. A. \& CURTISs, R., III, (1990 b). Conservation of Salmonella typhimurium virulence plasmid maintenance regions among Salmonella serovars as a basis for plasmid curing. Infection and Immunity 58, 3084-3092.

WARD, L. R., DE SA, J. D. H. \& Rowe, B. (1987). A phage-typing scheme for Salmonella enteritidis. Epidemiology and Infection 99, 291294.

WoOdWard, M. J., McLaren, I. \& Wray, C. (1989). Distribution of virulence plasmids within salmonellae. Journal of General Microbiology 135, 503-511.

Watanabe, T., Nishida, H., Ogata, C., Aral, T. \& Sato, S. (1964). Episome-mediated transfer of drug resistance in Enterobacteriaceae. Journal of Bacteriology 88, 716-726.

Williamson, C. M., Baird, G. D. \& Manning, E. J. (1988). A common virulence region on plasmids from eleven serotypes of Salmonella. Journal of General Microbiology 134, 975-982.

WILLETTS, N. \& SkURRAY, R. (1980). The conjugation system of F-like plasmids. Annual Review of Genetics 14, 41-76. 